\title{
Marx a rok 1968
}

Letošní rok je rokem mnoha výročí. Dvě z nich mají přitom řadu styčných bodů. V květnu jsme si připomněli 200 let od narození Karla Marxe, v srpnu si připomínáme 50 let od invaze vojsk Varšavské smlouvy do Československa, která ukončila tzv. obrodný proces označovaný jako Pražské jaro. Jak tento obrodný proces, tak i studentské bouře, které se v roce 1968 prohnaly západní Evropou, byly do značné míry inspirovány myšlenkami, které se odvolávaly na Marxe, i když v domácím prostředí šlo o myšlenky, jež směřovaly proti tomu, co bylo za pravou a jedině správnou verzi marxismu vydáváno vládnoucí mocí.

Dvěma základními motivy kritiky ze strany domácích, k marxismu se hlásících intelektuálů (Jiří Cvekl, Robet Kalivoda, Karel Kosík, Karel Michňák, Lubomír Sochor, Eduard Urbánek aj.), pro něž používala vládnoucí moc označení revizionisté, bylo v druhé polovině 60. let: a) přesvědčení, že ideologicky a mocensky prosazovaná verze marxistické doktríny není tou nejsprávnější interpretací Marxových myšlenek (především proto, že je velmi rigidní, uzavřená novým idejím, a především stále ještě výrazně kontaminovaná stalinismem), a b) kritický postoj k tehdejšímu politickému systému, jehož podoba neodpovídala představám svobodné společnosti, kterou měl podle jejich názoru na mysli Marx.

Pokud jde o pojmové instrumentárium této kritiky, které bylo s odkazem na Marxe využíváno, můžeme říci, že jedním z nosných konceptů této doby se stal pojem odcizení. Byl to pojem, jenž významně ovlivňoval také západní levicové myšlení, a podněcoval sociální imaginaci revoltujících skupin mládeže i úsilí nových sociálních hnutí.

Marx, jak známo, poprvé zformuloval náčrt teorie odcizení v Ekonomicko-filosofických rukopisech z roku 1844 (poprvé vyšly až 1932), avšak komplexní pohled na tuto problematiku mu poskytly teprve jeho pozdější analýzy fungování kapitalistické ekonomiky v Kapitálu. Marxovi bývalo někdy vytýkáno, že v Kapitálu chybí člověk jako individuum, že pro věci zapomíná na lidi. Francouzský, marxisticky orientovaný strukturalista Louis Althusser to dokonce pokládal za přednost marxismu a koncipoval marxistickou filozofii jako „teoretický antihumanismus“, který se obejde bez teoretických služeb pojmu člověk, pojmu, jenž byl podle Althussera z vědeckého hlediska nepoužitelný. Kritikové tohoto názoru však argumentují tvrzením, že Marx ve skutečnosti člověka popisuje a analyzuje, a sice tak, jak reálně v rámci kapitalistického výrobního způsobu existuje, totiž jako skrytého za svými produkty, které se proti němu staví a ovládají jej jako nějaká vnější síla.

V západním myšlení našly úvahy o odcizení odezvu především ve dvou filozofických směrech. Jedním z nich byl francouzský existencialismus, rozvíjený autory (Jean-Paul Sartre, Simone de Beauvoir, Albert Camus), v jejichž díle se objevuje postava člověka izolovaného od společnosti a dějinného vývoje, plného úzkosti a pocitu absurdity. Druhým byla kritická teorie, která se zformovala v Německu ve třicátých letech 20. století ve Frankfurtu 
nad Mohanem (Theodor W. Adorno, Max Horkheimer, Herbert Marcuse, Erich Fromm aj.) a jež postavila proti myšlence proletářské revoluce ideu společenské emancipace.

Pro tvorbu frankfurtské školy se po druhé světové válce stal charakteristickým pesimismus; představa, že historický proces směřuje nikoli k realizaci emancipativních ideálů, nýbrž k světu, který je totálně ovládán odcizenými společenskými silami a který vede k zániku individuality. Emblematickým dílem tohoto zaměření je Marcuseho Jednorozměrný člověk z roku 1964. Autor v něm představuje soudobou západní společnost jako společnost iracionální, jejíž duchovní a materiální vyspělost není využita k svobodnému rozvoji lidských potřeb, ale k ovládání individuí. Marcuse spatřuje aspekty odcizení nejen v ekonomické základně, ale také v politice, technice, kultuře a jazyce. Je to společnost, která namísto svobody nabízí masový konzum spojený se vštěpováním umělých, nepravých potřeb a s manipulací, jež vede $\mathrm{k}$ tomu, že v lidech formuje jednorozměrné myšlení a chování.

Vrátíme-li se k české intelektuální scéně 60. let, můžeme za všechny připomenout jednu osobnost, kterou byl germanista Eduard Goldstücker, jenž v roce 1963 inicioval mezinárodní odbornou konferenci o Franzi Kafkovi v Liblicích. Goldstücker ve svých pamětech uvádí, že v srpnu 1968 prrišla propaganda Německé demokratické republiky dokonce s tvrzením, že kontrarevoluce v Československu začala právě na této kafkovské konferenci.

Goldstückerův zájem o Kafku měl dvojí motivaci. Prvním motivem byla jeho snaha zařadit tohoto autora, který byl v socialistických zemích přehlížen jako představitel úpadkové západní kultury, do oficiálních dějin literatury. Druhým motivem byla snaha využít jeho filozofický potenciál pro kritiku současné společnosti. Jedním z charakteristických rysů Goldstückerova př́stupu byla snaha ukázat na spojení mezi Kafkovou vizí světa a Marxovou teorií odcizení.

To, čím Goldstücker v této době nejvíce provokoval strážce ideologické čistoty marxismu-leninismu, bylo tvrzení, že odcizení existuje nejen na Západě, ale i v socialistických zemích. Goldstücker argumentoval tím, že zvlášt’ v dlouhé době přechodu od kapitalismu $\mathrm{k}$ socialismu se mohou objevovat takové situace, kdy lidé pocitují odcizení silněji, než za kapitalismu. Sám Goldstücker měl k tomu tvrzení - jako obět politických procesů z padesátých let - nepochybně i své osobní důvody.

Porozumět tomu, o co usilovali v druhé polovině 60. let reformními komunisté, není dnes úplně jednoduché ani pro ty, kteří patří k nové, mladé generaci levicově smýšlejících intelektuálů. Doba se změnila, zásadním zpo̊sobem se proměnily podmínky v naší zemi, a změnu doznal také odborný slovník. Díváme-li se na soudobé kritické myšlení, vidíme, že dochází k výraznému odklonu od vzorců, které v něm dominovaly v minulosti a ve kterých sehrávaly klíčovou roli marxovské koncepty „vykořistováni““ a „odcizeni““.

Pojem vykořistování je sice stále přítomný ve studiích a úvahách, které se zabývají historickým vývojem kapitalismu, ale pokud jde o problémy soudobého světa, je užíván stále méně. V současnosti se s ním setkáváme hlavně v pracích, které byly inspirovány teorií závislosti a které ukazují, jak jsou země tzv. periferie dodnes vykořistovány zeměmi centra, tedy Západu. V současnosti je to především koncepce světového systému, jíž rozvíjí Immanuel Wallerstein, anebo nejrůznější přístupy orientované na kritiku postkolonialismu a jeho praktik. Na pojem odcizení dnes narazíme jen zrrídka, a to především v sociologických studiích věnovaných otázkám práce a volného času. Jazyk soudobých levicových teoretiků byl v posledních dvou až třech desetiletích obohacen řadou nových 
výrazů. K pojmovým inovacím, jež tato doba přinesla, patří především pojmy „exkluze“ a „boj za uznání“.

Pojem exkluze patří k diskurzu, který se snaží převyprávět základní problémy soudobého světa tím způsobem, že přesouvá pozornost od vertikálních nerovností (chápaných jako rozdíl mezi bohatstvím a chudobou) k nerovnostem, jež jsou pojímány horizontálně, tedy jako odsouvání některých skupin lidí na okraj společnosti a jejich marginalizaci. Anthony Giddens ve své práci Třetí cesta konstatuje, že se koncept sociální exkluze nevztahuje ke stupňování nerovností, ale k mechanismům, jež mají za následek oddělování určitých skupin od hlavního proudu společnosti. I když výraz sociální exkluze nadále souvisí s nerovností, nejedná se jen o třídní rozdíly, ale také o nerovnosti založené na genderové, etnické, kulturní či náboženské odlišnosti.

Teorii „boje o sociální uznáni““ vypracoval německý filozof a sociolog Axel Honnteth. Tvrdí, že spravedlnost a blaho v současných společnostech by měly být poměřovány především podle stupně, v němž jsou schopny zajistit podmínky vzájemného uznání pro různé skupiny obyvatel. Ty se ovšem svých nároků musí velmi často domáhat bojem, který Honneth charakterizuje jako „boj za uznání. Velmi inspirativní se v tomto směru stalo Honnethovo myšlení např́iklad pro současné představitelky feministického hnutí.

Jak je zřejmé, ohlédnutí za letošními výročími nabízí - pokud jde o myšlenkové tradice - obojí, kontinuitu i diskontinuitu. Pro historickou sociologii je to podnět a prríležitost k tomu, aby se zaměřovala nejen na sledování změn, které přinášejí společenské vývojové procesy, ale také na proměny idejí a konceptů, v nichž jsou tyto procesy zachycovány.

Jiři Šubrt

DOI: $10.14712 / 23363525.2018 .56$ 